\title{
Development of a simple chromogenic factor VIII assay for clinical use
}

Citation for published version (APA):

Wagenvoort, R. J., Hendrix, H. H., \& Hemker, H. C. (1989). Development of a simple chromogenic factor VIII assay for clinical use. Haemostasis, 19(4), 196-204. https://doi.org/10.1159/000215917

Document status and date:

Published: 01/01/1989

DOI:

10.1159/000215917

Document Version:

Other version

\section{Please check the document version of this publication:}

- A submitted manuscript is the version of the article upon submission and before peer-review. There can be important differences between the submitted version and the official published version of record.

People interested in the research are advised to contact the author for the final version of the publication, or visit the DOI to the publisher's website.

- The final author version and the galley proof are versions of the publication after peer review.

- The final published version features the final layout of the paper including the volume, issue and page numbers.

Link to publication

\footnotetext{
General rights rights.

- You may freely distribute the URL identifying the publication in the public portal. please follow below link for the End User Agreement:

www.umlib.nl/taverne-license

Take down policy

If you believe that this document breaches copyright please contact us at:

repository@maastrichtuniversity.nl

providing details and we will investigate your claim.
}

Copyright and moral rights for the publications made accessible in the public portal are retained by the authors and/or other copyright owners and it is a condition of accessing publications that users recognise and abide by the legal requirements associated with these

- Users may download and print one copy of any publication from the public portal for the purpose of private study or research.

- You may not further distribute the material or use it for any profit-making activity or commercial gain

If the publication is distributed under the terms of Article $25 \mathrm{fa}$ of the Dutch Copyright Act, indicated by the "Taverne" license above, 


\title{
Development of a Simple Chromogenic Factor VIII Assay for Clinical Use
}

\author{
R.J. Wagenvoord, H.H. Hendrix, H.C. Hemker \\ Department of Biochemistry, University of Limburg, Maastricht, The Netherlands
}

Key Words. Factor VIII · Factor X activating complex · Chromogenic assay

\begin{abstract}
The aim of this study was the development of a simple chromogenic factor VIII assay for practical clinical use. The criteria that the assay fulfils are: (1) The method is so sensitive that even $1 \%$ factor VIII in human plasma is easily detected. (2) The method is linear in the amount of factor VIII from 0 to $200 \%$ in plasma. (3) The pipetting scheme is very simple; two reagents are prepared, reagent 1 (factor IXa, thrombin, $\mathrm{Ca}^{2+}$ and phospholipids) and reagent 2 (factor $\mathrm{X}$ ). Then we pipet at $\mathrm{t}=0 \mathrm{~s}, 100 \mu \mathrm{l}$ diluted plasma $+100 \mu \mathrm{l}$ reagent 1 in a reaction tube; at $t=30 \mathrm{~s}, 100 \mu \mathrm{l}$ reagent 2 in the same tube and at $\mathrm{t}=90 \mathrm{~s}$, $200 \mu \mathrm{l}$ of the reaction mixture in a cuvette with $700 \mu$ l EDTA buffer (stop buffer) and the formed factor $\mathrm{Xa}$ is measured with a chromogenic substrate. (4) The reaction components are stable during at least a whole working day. Factor VIII was measured in an assay using bovine clotting factors, so one avoids the risk of viral infections, which one might catch by working with clotting factors isolated from human plasma.
\end{abstract}

\section{Introduction}

For practical clinical use we developed an assay for factor VIII in human plasma. Some work concerning the development of this assay [1] and its practical use [2] was already presented at the congress on Thrombosis and Haemostasis in Brussels, 1987. In order to be of practical suitability, the assay must be very sensitive (less then $1 \%$ factor VIII must be detectable), the assay must be linear from 0 to $200 \%$ factor VIII in plasma, the pipetting steps should be as minimal as possible and the reaction components should be stable during a whole working day.
The activation of the zymogen factor $\mathrm{X}$ into factor $\mathrm{Xa}$ by the serine protease factor IXa [review in ref. 3] is strongly increased by negatively charged phospholipids, $\mathrm{Ca}^{2+}$ ions and activated factor VIII [review on factor VIII in ref. 4]. The complex of factor IXa, factor VIIIa, $\mathrm{Ca}^{2+}$ and phospholipids is called the intrinsic factor $\mathrm{X}$ activating complex, or intrinsic factor $X$ activator [5-9]. Van Dieijen et al. [10] described the conditions for optimal interaction of bovine factor VIIIa in the assembly of the factor X activating complex. In their article they showed that a complete factor $\mathrm{X}$ activating complex will activate about 900 molecules factor $\mathrm{X}$ 
per minute. Thus, under conditions that the activated factor VIII is completely bound in the factor $\mathrm{X}$ activating complex, 900 molecules factor $\mathrm{Xa}$ are formed per minute per molecule factor VIIIa. Factor Xa can be measured with a chromogenic substrate. So, if one chooses the right conditions a small amount of factor VIIIa can form a large amount of factor $\mathrm{Xa}$ and in this way a sensitive factor VIII assay is obtained. However, we deal with human factor VIII which may act differently from bovine factor VIII, for which the optimal conditions for a good assay are described [10]. There are two possible approaches, one can use either human clotting factors, or bovine clotting factors in the factor VIII assay. We strongly favored the use of bovine clotting factors for the following reasons. Bovine blood is easy to obtain in large quantities in contrast to human blood, isolation procedures for the purification of bovine clotting factors are well described and finally one avoids the risk of viral infections using bovine plasma instead of human plasma.

We investigated if bovine clotting factors are suitable for a human factor VIII assay, which was proven to be the case. To obtain a system as sensitive as possible we have varied each of the reaction components of the factor $\mathrm{X}$ activating complex to determine their optimal concentrations.

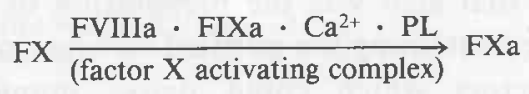

We successively searched for the optimal conditions for factor VIII activation with thrombin, the optimal factor IXa concentrations to bind all factor VIIIa, the optimal phospholipid concentration and composition to obtain a rapid factor $\mathrm{Xa}$ formation and finally the optimal $\mathrm{pH}$ for factor $\mathrm{X}$ activation.
To determine the required factor $\mathrm{X}$ concentration we measured its $\mathrm{K}_{\mathrm{m}}$ for the complex. When all conditions were optimal, a turnover rate was obtained of $1,400 \mathrm{~mol}$ factor $\mathrm{Xa}$ formed per minute and mole factor VIIIa. We also investigated the suitability of the chromogenic substrate $\left(\mathrm{CH}_{3} \mathrm{OCO}-\mathrm{D}\right.$-CHG-Gly-ArgpNA-AcOH) for the assay. It was shown that it is suitable for our purposes, however, a thrombin inhibitor $\alpha$-NAPAP [N- $\alpha$-(2-naphtylsulfonylglycyl)- $D, L$-amidinophenyl-alanine-piperidide hydroidide] should be added, to inhibit the large amount of thrombin which is present in the assay mixture for complete factor VIII activation.

Stability studies showed lyophilized reagents could be stored for several months without loosing their activity and that reconstituted reagents were stable for at least a whole working day. Moreover, we showed that the assay was linear from 0 to $200 \%$ factor VIII in plasma and that less than $1 \%$ factor VIII could be well detected.

\section{Materials and Methods}

\section{Materials}

FXa-substrate $\left(\mathrm{CH}_{3} \mathrm{OCO}-\mathrm{D}\right.$-CHG-Gly-Arg-pNA$\mathrm{AcOH})$ and $\alpha$-NAPAP [ $\mathrm{N}-\alpha$-(2-naphtylsulfonylglycyl)- $D, L$-amidinophenyl-alanine-piperidide hydroidide] were obtained from Pentapharm, Switzerland; DEAE-Sephadex and Sepharose-4B were from Pharmacia, Sweden; Heparin-Agarose was kindly donated by $T$. Janssen-Claessen.

All other reagents were of the highest grade available and were supplied by either Merck (FRG) or Sigma (USA).

Phospholipids and Phospholipid vesicles

Phosphatidyl choline was extracted from egg yolks according to Bligh and Dyer [11] and purified as described by Comfurius and Zwaal [12]. Phosphatidyl serine and phosphatidyl ethanolamine were prepared in a similar way, however, extracted from bo- 
vine brains. Vesicles were prepared by sonication of a phospholipid mixture in a buffer containing $50 \mathrm{mM}$ Tris- $\mathrm{HCl}$ and $175 \mathrm{mM} \mathrm{NaCl}$ (pH 7.9) using an MSE Mark II 150-Watt ultrasonic disintegrator set at $9 \mu$ peak to peak amplitude. The composition of the vesicles was $75 \mathrm{~mol} \%$ phosphatidyl choline and $25 \mathrm{~mol} \%$ phosphatidyl serine or as indicated.

\section{Proteins}

Bovine factor $\mathrm{X}$ was isolated according to Fujikawa et al. [13] and bovine factor IXa as described by van Dieijen et al. [8]. Thrombin was prepared as described by Wagenvoord et al. [14]. As reference plasma ( $100 \%$ factor VIII) a normal pooled citrated plasma was used that was prepared from 15 healthy donors (donated by T. Janssen-Claessen). Congenital factor VIII deficient plasma was kindly donated by $T$. Repucci (Centre de Transfusion, Liège, Belgium). Plasmas containing more than $100 \%$ factor VIII were prepared by mixing reference plasma with a cryoprecipitate $(10 \mathrm{U} / \mathrm{ml})$.

\section{Results}

Properties of the Chromogenic Substrate $\mathrm{CH}_{3} \mathrm{OCO}-\mathrm{D}-\mathrm{CHG}-\mathrm{Gly}$-Arg- $\mathrm{PNA}-\mathrm{AcOH}$

We have studied the kinetic properties of the factor $\mathrm{Xa}$ substrate $\mathrm{CH}_{3} \mathrm{OCO}-\mathrm{D}$-CHGGly-Arg-pNA-AcOH (FXa-substrate). First we determined the kinetic constants of FXasubstrate hydrolysis by factor $\mathrm{Xa}$. For that reason a Lineweaver-Burk plot was made (fig. 1a). For $\mathrm{K}_{\mathrm{m}}$ we measured $142 \mu M$ and $\mathrm{V}_{\max }$ was $386 \mathrm{n} M$ p-nitroanilide liberated/ $\mathrm{s} \cdot \mathrm{n} M$ factor $\mathrm{Xa}$, or 229.5 milliabsorbance units/n $M$ factor $\mathrm{Xa} \cdot \mathrm{min}$. Remarkable is the effect of a high $\mathrm{NaCl}$ concentration on $\mathrm{K}_{\mathrm{m}}$, which becomes $27.3 \mu \mathrm{M}$ in the presence of $2.5 \mathrm{M} \mathrm{NaCl}, \mathrm{V}_{\max }$, however, does not change by the increased $\mathrm{NaCl}$ concentration. Thus, by addition of $\mathrm{NaCl}$ the affinity of the $\mathrm{FXa}$ substrate for factor $\mathrm{Xa}$ increases, which leads to a higher rate of hydrolysis.

Since in the factor VIII assay mixture a large amount of thrombin is present, it was necessary to determine the kinetic constants of the FXa substrate hydrolysis by thrombin. Figure 1b shows that FXa substrate is hydrolysed by thrombin, however, much slower than factor $\mathrm{Xa} . \mathrm{V}_{\max }$ is $12.6 \mathrm{n} M$ p-nitroanilide liberated/s $\cdot \mathbf{n} M$ thrombin or $7.52 \mathrm{mil}$ liabsorbance units/ $\mathrm{n} M$ thrombin.min and $\mathrm{K}_{\mathrm{m}}$ is $59.0 \mu M$. In reagent 1 of the FVIII assay a large amount of thrombin is present (fig. 6), which causes a very rapid hydrolysis of the FXa substrate, so it cannot be used unless an effective thrombin inhibitor is present which does not inhibit factor $\mathrm{Xa}$.

Figure 2 shows that the thrombin inhibitor $\alpha$-NAPAP is able to inhibit thrombin effectively without inhibiting factor $\mathrm{Xa}$ very much. At a concentration of $1 \mu M \alpha$ NAPAP, thrombin is inhibited by $99.5 \%$, but factor Xa only by $1 \%$. By using $1 \mu M$ $\alpha$-NAPAP (final concentration in the cuvette), the hydrolysis rate of FXa-substrate by thrombin is brought back to $21.8 \mathrm{nM}$ / min, which is only $1 \%$ of the rate to be expected by the factor $\mathrm{Xa}$ formed in an assay with normal plasma.

On basis of the results of figures 1 and 2 factor $\mathrm{Xa}$ was measured by addition of $100 \mu \mathrm{FXa}$ substrate $(800 \mu M)$ plus $10 \mu M$ $\alpha$-NAPAP to $900 \mu 1$ of a factor Xa sample.

\section{Preparation of a Factor VIII Assay \\ Mixture}

Our first goal was the preparation of a mixture containing the purified bovine clotting factors which could detect human plasma factor VIII as sensitive as possible, therefore we varied each of the components of the factor $\mathrm{X}$ activating complex to determine their optimal concentration.

In figure $3 \mathrm{a}$ we studied the effect of thrombin on factor VIII activation in human plasma. Maximal factor VIII activation oc- 


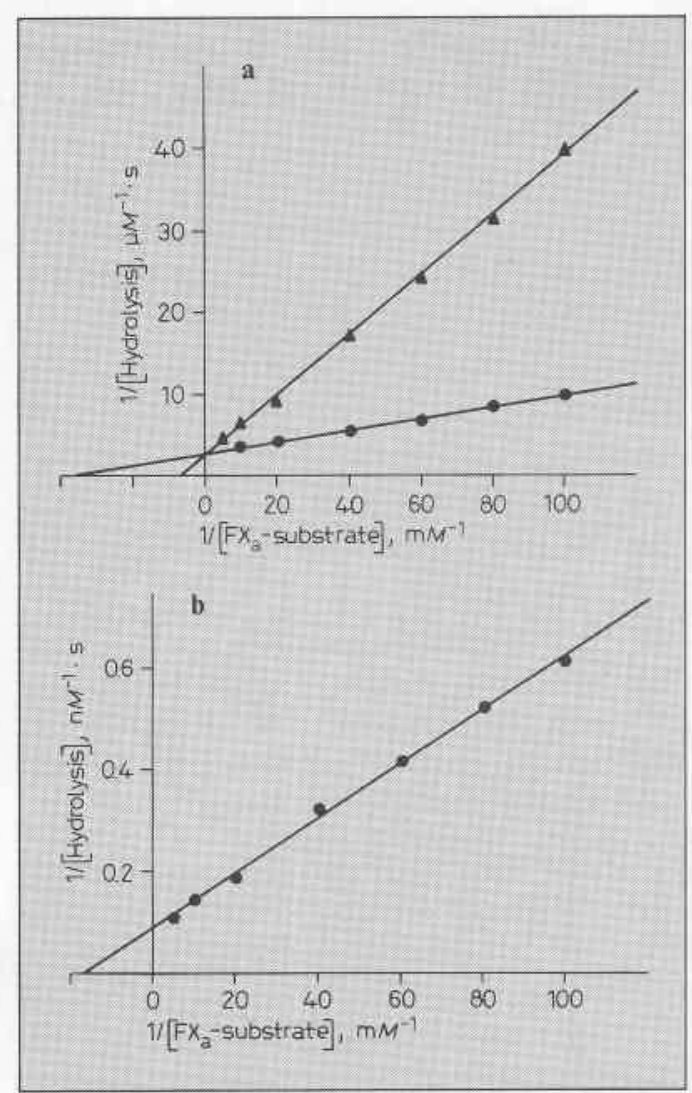

Fig. 1. Lineweaver-Burk plots of FXa-substrate hydrolysis by factor Xa and thrombin. a Plot of FXasubstrate hydrolysis by factor Xa. The factor Xa concentration was $1 \mathrm{n} M . \bullet=$ The experiment was done in standard buffer $(175 \mathrm{mM} \mathrm{NaCl}, 50 \mathrm{~m} M$ Tris- $\mathrm{HCl}$ (pH 7.9), $0.5 \mathrm{mg} / \mathrm{ml}$ human serum albumin); $\Delta=$ experiment in which a buffer with $2.5 \mathrm{M} \mathrm{NaCl}$ is used. b Plot of FXa-substrate hydrolysis by thrombin. The thrombin concentration was $1 \mathrm{n} M$ and standard buffer was used.

curs at thrombin concentrations of $30 \mathrm{n} M$ or more. The presence of more than $30 \mathrm{n} M$ thrombin does not lead to more factor VIIIa formation, however, it is preferable to have a large excess of thrombin in the assay because of the presence of antithrombin III and $\alpha_{2}$ macroglobulin in the plasma, which will inac-

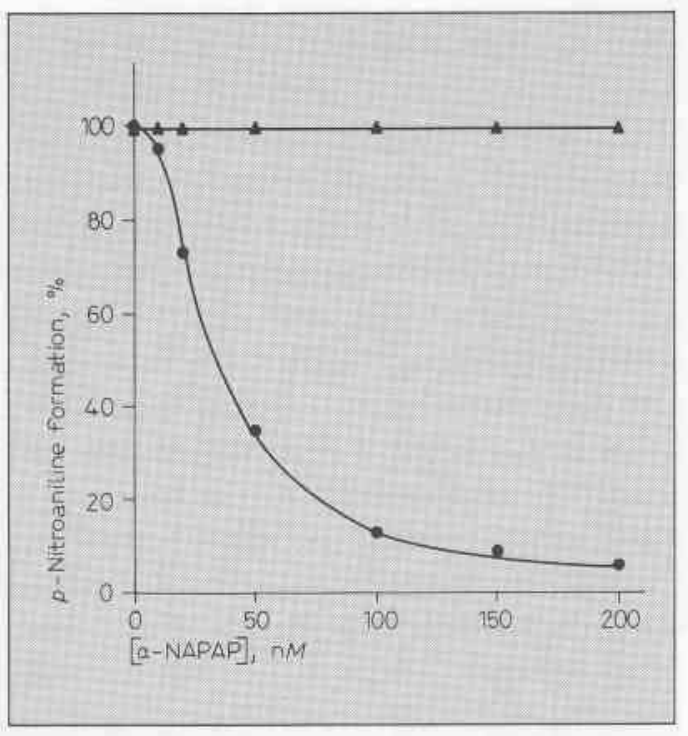

Fig. 2. Effect of $\alpha$-NAPAP on FXa-substrate hydrolysis by factor Xa and thrombin. The cuvette contained $20 \mathrm{n} M$ thrombin $(\bullet)$ or $0.75 \mathrm{n} M$ factor $\mathrm{Xa}(\boldsymbol{\Delta})$, $80 \mu M \mathrm{FXa}$-substrate and $\alpha$-NAPAP. The increase of the absorption at $405 \mathrm{~nm}$ was measured at $37^{\circ} \mathrm{C}$. The activities in the absence of $\alpha$-NAPAP were taken as $100 \%$.

tivate the thrombin. An additional advantage of excess of thrombin is that it will saturate all plasma serine protease inhibitors and thus formed factor $\mathrm{Xa}$ is not inactivated.

Figure $3 b$ shows the effect of factor IXa concentration on the factor $\mathrm{Xa}$ formation by the factor $\mathrm{X}$ activating complex. The reaction rate is a reflection of binding of factor VIIIa into the complex. The figure shows that optimal binding occurs when the factor IXa concentration is $50 \mathrm{n} M$ or higher.

In figures $3 c$ and $d$ the effect is shown of phospholipids on the activation of bovine factor $\mathrm{X}$ by the factor $\mathrm{X}$ activating complex composed of bovine factor IXa, human factor VIIIa and $\mathrm{Ca}^{2+}$. Figure $3 \mathrm{c}$ shows the effect of varying amounts of phosphatidyl ser- 


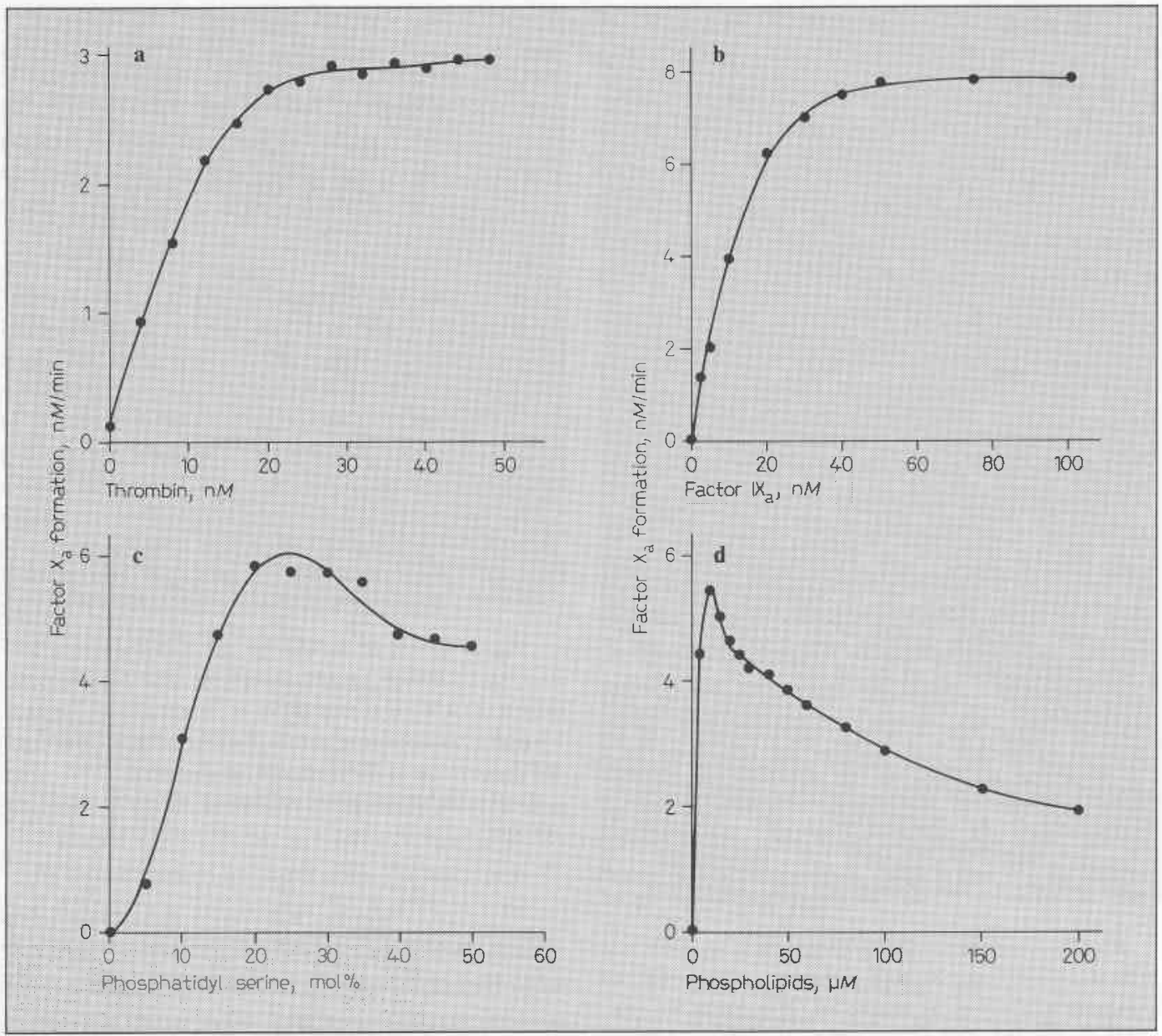

Fig. 3. Optimization of the human factor VIII assay. a Activation of human plasma factor VIII with thrombin: to $200 \mu$ f factor IXa $(200 \mathrm{n} M), \mathrm{CaCl}_{2}(10$ $\mathrm{m} M$ ), phospholipids ( $40 \mu M ; 75 \mathrm{~mol} \%$ phosphatidyl choline, $25 \mathrm{~mol} \%$ phosphatidyl serine) $100 \mu \mathrm{l}$ thrombin were added. At $t=0$ s $50 \mu l 10$ times diluted human plasma were added and at $\mathrm{t}=30 \mathrm{~s} 50 \mu \mathrm{l}$ factor $\mathrm{X}$ $(2 \mu M)$. Samples of $300 \mu l$ were taken at $t=60 \mathrm{~s}$ and the factor Xa formation was measured. To stop further factor Xa formation the samples were pipetted into $600 \mu 1$ EDTA $(20 \mathrm{~m} M)$. b Effect of the factor IXa concentration on the rate of factor Xa formation: to $200 \mu \mathrm{l}$ thrombin $(100 \mathrm{n} M), \mathrm{CaCl}_{2}(10 \mathrm{~m} M)$, phospholipids ( $40 \mu M ; 75 \mathrm{~mol} \%$ phosphatidyl choline, $25 \mathrm{~mol} \%$ phosphatidyl serine) $100 \mu \mathrm{l}$ factor IXa were added. At $\mathrm{t}=0 \mathrm{~s} 50 \mu \mathrm{l} 10$ times diluted human plasma were added and at $\mathrm{t}=30 \mathrm{~s} 50 \mu \mathrm{l}$ factor $\mathrm{X}(2 \mu M)$. Samples of $300 \mu \mathrm{l}$ were taken at $\mathrm{t}=90 \mathrm{~s}$ and the factor $\mathrm{Xa}$ formation was measured. $\mathbf{c}, \mathbf{d}$ Effect of phospholipid composition and concentration on the rate of factor Xa formation: to $200 \mu$ l thrombin $(200 \mathrm{n} M), \mathrm{CaCl}_{2}(10 \mathrm{mM})$, factor IXa $(200 \mathrm{n} M) 100 \mu 1$ phospholipids were added. At $\mathrm{t}=0 \mathrm{~s}$ $50 \mu 10$ times diluted human plasma were added and at $\mathrm{t}=30 \mathrm{~s} 50 \mu \mathrm{l}$ factor $\mathrm{X}(2 \mu M)$. Samples of $300 \mu \mathrm{l}$ were taken at $\mathrm{t}=90 \mathrm{~s}$ to measure the formed factor $\mathrm{Xa}$. c The vesicles concentration was kept at $20 \mu \mathrm{M}$, whereas the composition was varied. The phosphatidyl serine content was $0-50 \mathrm{~mol} \%$ and the phosphatidyl choline content $100-50 \mathrm{~mol} \%$. d Effect of phospholipid concentration on the rate of factor Xa formation. The vesicle composition was kept at $25 \mathrm{~mol} \%$ phosphatidyl serine and $75 \mathrm{~mol} \%$ phosphatidyl choline. 


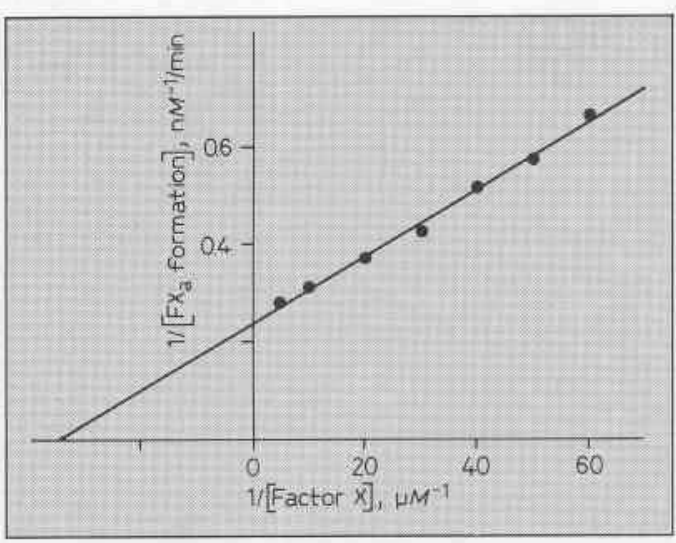

Fig. 4. Lineweaver-Burk plot of factor $\mathrm{X}$ activation by the factor $\mathrm{X}$ activating complex composed of bovine factor IXa and human factor VIIa. To $200 \mu \mathrm{l}$ thrombin $(200 \mathrm{n} M), \mathrm{CaCl}_{2}(10 \mathrm{~m} M)$, factor IXa (200 $\mathrm{n} M$ ) phospholipids ( $40 \mu M ; 25 \mathrm{~mol} \%$ phosphatidyl serine, $75 \mathrm{~mol} \%$ phosphatidyl choline) at $\mathrm{t}=0 \mathrm{~s}$ $100 \mu 120$ times diluted human plasma were added. At $\mathrm{t}=30 \mathrm{~s} 100 \mu \mathrm{l}$ factor $\mathrm{X}(67-800 \mathrm{n} M)$ were added. Samples of $300 \mu \mathrm{l}$ were taken at $t=90 \mathrm{~s}$ to measure the formed factor Xa.

ine in the vesicles (fixed concentrations) on the factor $\mathrm{X}$ activating reaction: maximal activity is found at a phosphatidyl serine concentration of around $25 \mathrm{~mol} \%$. In figure $3 \mathrm{~d}$ one can observe a rapid increase of the enzymatic activity when the phospholipid concentration (with fixed composition) increases from 0 to $10 \mu M$, then becomes maximal and subsequently slows down at still higher phospholipid concentrations. This result is in agreement with an earlier report [8], however, valid for proteins which all were isolated from bovine blood.

We also have investigated the effect of phosphatidyl ethanolamine and cholesterol addition to the vesicles. When a phosphatidyl choline/phosphatidyl serine ratio of 3 is maintained and either phosphatidyl ethanolamine or cholesterol is added, there is no effect at low concentrations of both compounds. However, when phosphatidyl ethanolamine is present in a concentration of more than $15 \mathrm{~mol} \%$, the activity of the vesicles drops. For cholesterol the same effect is found at concentrations of more than 20\% $(w / w)$. So we can conclude that vesicles of a composition of $25 \mathrm{~mol} \%$ phosphatidyl serine and $75 \mathrm{~mol} \%$ phosphatidyl choline have an optimal activity, which cannot be improved by addition of other compounds.

Figure 4 shows the Lineweaver-Burk plot of factor $\mathrm{X}$ activation by the complete factor $\mathrm{X}$ activating complex. The two kinetic parameters that can be derived from the figure are $\mathrm{K}_{\mathrm{m}}$, which is $31.4 \mathrm{n} M$, and $\mathrm{V}_{\max }$, which is 241 milliabsorbance units/min, when a 20 times diluted reference plasma is used (11.7 $\mathrm{n} M$ factor $\mathrm{Xa} / \mathrm{min})$.

We also have investigated the effect of the $\mathrm{pH}$ on the complete factor $\mathrm{X}$ activating complex (containing bovine factors, but human factor VIIIa). The activity showed a broad maximum between $\mathrm{pH} 7.6$ and 8.5 , whereas at lower and higher $\mathrm{pH}$ values the activity decreased. As a result of these experiments we decided to use buffers with $\mathrm{pH}$ 7.9.

In figure 5 we have measured factor $\mathrm{Xa}$ formation by time in an assay containing the human factor VIII and the other components of the factor $\mathrm{X}$ activating complex, which were present in optimal concentrations as judged from figures 3 and 4 . Two reagents were prepared: reagent 1 , containing $300 \mathrm{n} M$ factor IXa, $300 \mathrm{n} M$ thrombin, $15 \mathrm{~m} M \mathrm{CaCl}_{2}$ and $60 \mu \mathrm{M}$ phospholipid vesicles $(75 \mathrm{~mol} \%$ phosphatidyl choline and $25 \mathrm{~mol} \%$ phosphatidyl serine) and reagent 2 containing $1 \mu M$ factor X. By mixing 1 part reagent 1, 1 part diluted plasma and 1 part reagent 2 , the final concentrations of each of the clotting factors were optimal for maximal factor Xa forma- 
5

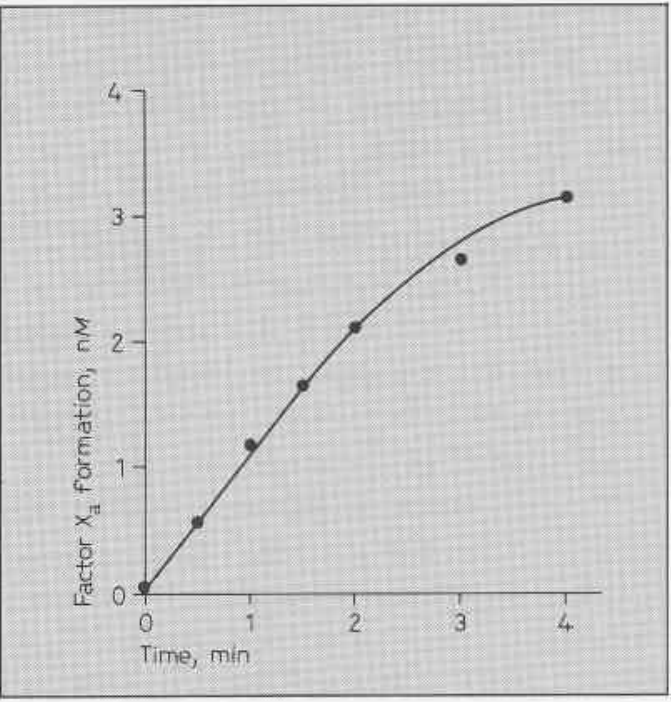

Fig. 5. Linearity of the factor $\mathrm{X}$ activating reaction. To $1 \mathrm{ml}$ of $300 \mathrm{n} M$ factor IXa, $300 \mathrm{n} M$ thrombin, $60 \mu M$ phospholipids ( $75 \mathrm{~mol} \%$ phosphatidyl choline, $25 \mathrm{~mol} \%$ phosphatidyl serine), $15 \mathrm{mM} \mathrm{\textrm {CaCl } _ { 2 }}$ at $\mathrm{t}=0 \mathrm{~s} 1 \mathrm{ml} 100$ times diluted human plasma was added. At $\mathrm{t}=30 \mathrm{~s} 1 \mathrm{ml}$ factor $\mathrm{X}(1 \mu M)$ was added. Samples of $200 \mu$ l were taken in time to measure formed factor Xa.

Fig. 6. Stability of lyophilized FVIII-assay reagents. Two reagents were lyophilized in amounts of $1 \mathrm{ml}$. Reagent 1 contained $300 \mathrm{n} M$ factor IXa,

tion. The solutions were made in a buffer containing $175 \mathrm{~m} M \mathrm{NaCl}, 50 \mathrm{~m} M$ Tris- $\mathrm{HCl}$, $0.5 \mathrm{mg} / \mathrm{ml}$ ovalbumin ( $\mathrm{pH} 7.9$ ). In figure 5 it is shown that factor $\mathrm{Xa}$ formation by time is linear up to $1.5 \mathrm{~min}$, but then the rate of factor $\mathrm{Xa}$ formation decreases.

\section{Stability of the Factor VIII Assay \\ Reagents}

A point of practical importance is the stability of the reagents after preparation, lyophilization, storage and reconstitution. We prepared reagents 1 and 2. Reagent 1 containing $300 \mathrm{n} M$ thrombin, $300 \mathrm{n} M$ factor

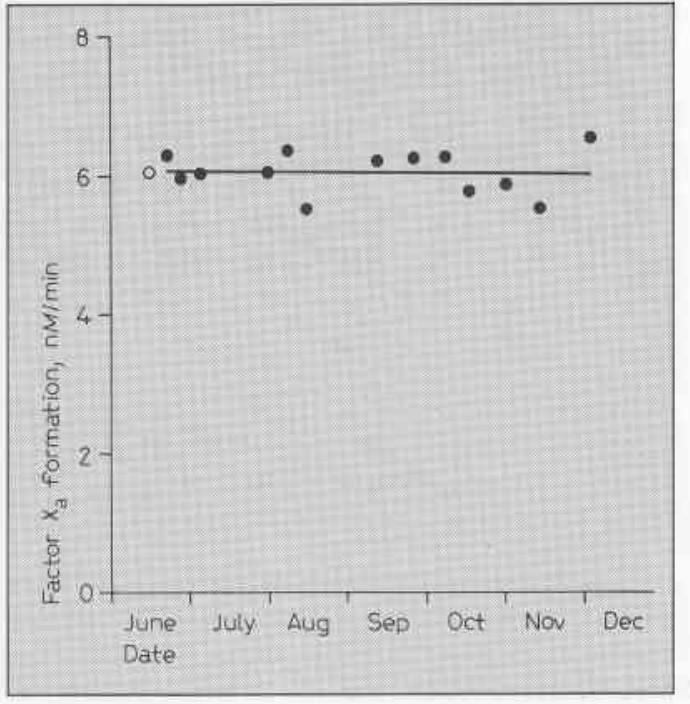

$300 \mathrm{n} M$ thrombin, $15 \mathrm{mM} \mathrm{CaCl}_{2}, 60 \mu M$ phospholipid vesicles $(75 \mathrm{~mol} \%$ phosphatidyl choline, 25 mol $\%$ phosphatidyl serine) and reagent 2 contained $1 \mu M$ factor $\mathrm{X}$. The activities of the reagents were tested before ( $(0)$ and after lyophilization, storage at $4{ }^{\circ} \mathrm{C}$ and reconstitution ( $\bullet$ ). The pipetting sequence was that at $t=0 \mathrm{~s} 100 \mu \mathrm{l}$ reagent 1 were mixed with $100 \mu \mathrm{l} 20$ times diluted human plasma, at $\mathrm{t}=$ $30 \mathrm{~s} 100 \mu \mathrm{l}$ reagent 2 were added and at $t=60 \mathrm{~s}$ $200-\mu \mathrm{l}$ samples were taken to measure formed factor $\mathrm{Xa}$.

IXa, $15 \mathrm{mM} \mathrm{CaCl} 2$ and $60 \mu M$ vesicles (75 mol\% phosphatidyl choline and $25 \mathrm{~mol} \%$ phosphatidyl serine), was lyophilized in portions of $2 \mathrm{ml}$. Also reagent 2 containing $1 \mu M$ factor $\mathrm{X}$ was lyophilized in this way. Both reagents were stored at $4{ }^{\circ} \mathrm{C}$. After reconstitution they were tested. We determined the protein concentrations in the reagents and the activity of the reagents in the factor VIII assay.

We determined the thrombin and factor IXa concentration in reagent 1 after reconstitution. The thrombin concentration varied from 258 to $290 \mathrm{nM}$ and the factor IXa 


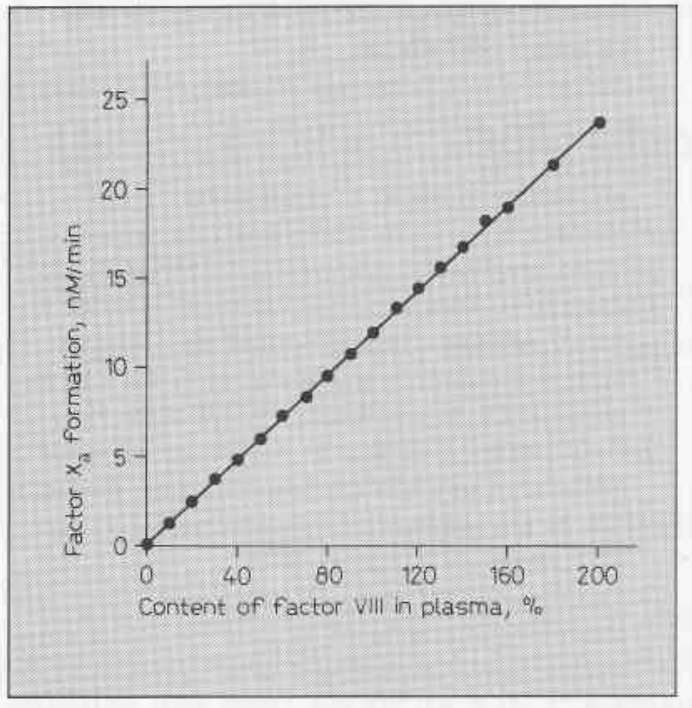

Fig. 7. Linearity of the FVIII assay. Plasmas were prepared containing $0-200 \%$ factor VIII (normal pooled plasma $=100 \%$ ) which were diluted 10 times. The reagents described in figure 6 were used and the same pipetting sequence was done, however, 200- $\mu$ l samples were taken at $90 \mathrm{~s}$.

concentration from 281 to $295 \mathrm{n} M$. After reconstitution we measured the factor $\mathrm{X}$ concentration in reagent 2 , which was $0.8-$ $1.0 \mu \mathrm{M}$. Also in this case there was not much loss of activity. Because the concentration of the proteins was chosen so that small changes in their concentration would not effect the factor VIII assay, we expected no change in the activity. In figure 6 this is shown. Before lyophilization and after reconstitution the activity was the same and, moreover, the activity remained at the starting level even after half year of storage of the lyophilized reagents.

We also tested the stability of the reagent after reconstitution during the working day and after storage at $4{ }^{\circ} \mathrm{C}$ during the night. The activities are expressed in percentages: before lyophilization, $100 \%$; on day 1 , after reconsti- tution of the reagents, the activities were $101 \%$ at $10.00 \mathrm{~h}$ and $101 \%$ at $17.00 \mathrm{~h}$. At day 3 at $11.00 \mathrm{~h}$, the activity was $93 \%$. In other experiments similar results were found.

\section{Sensitivity of the Factor VIII Assay}

Finally we have tested the sensitivity of the chromogenic factor VIII assay by measuring plasmas containing $0-200 \%$ factor VIII. In figure 7 the results of these tests are shown. One can observe a complete linearity between the factor VIII content of the plasma and the factor $\mathrm{Xa}$ formation in the reaction mixture. Plasma containing $1 \%$ factor VIII gives rise to a 2-3 times higher factor Xa formation than fully factor VIII deficient plasma, so one can easy measure $1 \%$ factor VIII in plasma. Using the same dilutions it is possible to measure $200 \%$ without underestimating the reaction rate. When we use normal pooled plasma $(100 \%$ factor VIII), about $12 \mathrm{n} M$ factor $\mathrm{Xa}$ is formed in the assay mixture, so in the cuvette $2.4 \mathrm{n} M$ factor Xa will be present, which gives an increase in absorbance of about 200 milliabsorbance units/min under the described reaction condition.

\section{Discussion}

In this article we described the development of a chromogenic factor VIII assay, which can be done in only a few pipetting steps. The test is linear from 0 to $200 \%$ factor VIII in human plasma. The reagents are stable when they are lyophilized for at least half a year and after reconstitution they do not loose activity during a whole working day. After reconstitution they can be stored at $4{ }^{\circ} \mathrm{C}$ and used during at least 3 days. Because of its simplicity the test can be auto- 
mated. A suggestion to minimize the pipetting steps is to mix the diluted plasma with factor X (reagent 2) and add the reagent 1 to this mixture. Then stop the reaction after 11.5 min with the EDTA buffer. When this sequence of pipetting is used, only two steps should be done at fixed times. In this case factor VIII activation precedes the formation of the complete factor $\mathrm{X}$ activating complex. However, this is not a real problem, because the time necessary for complete factor VIII activation is only a few seconds, since thrombin is present in high concentration and when the lag time is the same for all factor VIII concentrations, the linearity of the measurement is fully maintained.

If we compare human factor VIII with bovine factor VIII in respect to their action in the factor $\mathrm{X}$ activating complex, their resemblance is very close. The turnover rate of the factor $\mathrm{X}$ activating complex composed of only bovine factors is about $900 \mathrm{~min}^{-1}$ [10]. We can estimate this number from our results. In human plasma about $0.25 \mathrm{n} M$ factor VIII is present [10], so in the assay of figure 6 , $4.2 \mathrm{p} M$ factor VIIIa is present which gives a rate of $6 \mathrm{nMFXa} / \mathrm{min}$, so the turnover number is about $1,400 \mathrm{~min}^{-1}$, a value which is in the same order as was found for the bovine factor $\mathrm{X}$ activating complex.

\section{Acknowledgement}

We are grateful to Mrs. T. Camphuisen for typing the manuscript.

\section{References}

1 Wagenvoord R, Hendrix H, Hemker HC: Development of a simple factor VIII-assay for clinical use (Abstract). Thromb Haemost 1987;58:341.

2 Tran TH, Zühlke U, Hauert J, et al: Influence of heparin on factor VIII (FVIII) assay. Thromb Haemost 1987;58:341.

3 Jackson CM, Nemerson Y: Blood coagulation. Annu Rev Biochem 1980;49:765-811.

4 Hoyer LW: The factor VIII complex: Structure and function. Blood 1981;58:1-13.

5 Hemker HC, Kahn MJP: Reaction sequence of blood coagulation. Nature 1967;215:1201-1202.

6 Østerud B, Rapaport SI: Synthesis of intrinsic factor $\mathrm{X}$ activator. Inhibition of the function of formed activator by antibodies to factor VIII and to factor IX. Biochemistry 1970;9:1854-1861.

7 Hultin MB, Nemerson Y: Activation of factor X by factors IXa and VIII; a specific assay for factor IXa in the presence of thrombin activated factor VIII. Blood 1978;52:928-940.

8 Van Dieijen G, Tans G, Rosing J, et al: The role of phospholipid and factor VIIIa in the activation of bovine factor X. J Biol Chem 1981;256:34333442.

9 Griffith MJ, Reisner HM, Lundblad RL, et al: Measurement of human factor IXa activity in an isolated factor $\mathrm{X}$ activation system. Thromb Res 1982;27:289-301.

10 Van Dieijen G, van Rijn JLML, Govers-Riemslag JWP, et al: Assembly of the intrinsic factor $\mathrm{X}$ activating complex - interactions between factor IXa, factor VIIIa and phospholipid. Thromb Haemost 1985;53:396-400.

11 Bligh EG, Dyer WJ: A rapid method of total lipid extraction and purification. Can J Biochem Physiol 1959;37:911-917.

12 Comfurius P, Zwaal RFA: The enzymatic synthesis of phosphatidylserine and purification by $\mathrm{CM}$ cellulose column chromotography. Biochim Biophys Acta 1977;488:36-42.

13 Fujikawa K, Legaz ME, Davie EW: Bovine factor $\mathrm{X}_{1}$ and $\mathrm{X}_{2}$ (Stuart factor). Isolation and characterization. Biochemistry 1972;11:4882-4891.

14 Wagenvoord R, Hendrix H, Soria C, et al: Localization of the inhibitory site(s) of pentosan polysulphate in blood coagulation. Thromb Haemostasis $1988 ; 60: 220-225$.

Received: May 31, 1988

Accepted: December 22, 1988

\section{R.J. Wagenvoord, MD}

Department of Biochemistry

University of Limburg, PO Box 616

NL-6200 MD Maastricht (The Netherlands) 